\title{
EFFECT OF PELLETED BROWSE-BASED FEED WITH A BASAL DIET OF Andropogon gayanus FOR SHEEP ON INTAKE, NUTRIENT DIGESTIBILITY AND SOME HAEMATOLOGICAL AND BLOOD BIOCHEMICAL PARAMETERS
}

\author{
Leonard ADJORLOLO ${ }^{1}$, Mark NSOH², Akwasi MENSAH-BONSU³ and Frederick OBESE2 ${ }^{2 \times 凶}$ \\ ${ }^{1}$ Livestock and Poultry Research Centre, School of Agriculture, University of Ghana, Legon, Ghana \\ 2 Department of Animal Science, School of Agriculture, University of Ghana, Legon, Ghana \\ ${ }^{3}$ Department of Agricultural Economics and Agribusiness, School of Agriculture, University of Ghana, Legon, Ghana \\ Email: fobese@ug.edu.gh; (D)RCiD: 0000-0001-6747-4786 \\ Supporting Information
}

\begin{abstract}
The study was designed to evaluate the nutritional quality of pelleted diets based on four of the major feed resources fed to small ruminants by farmers in the Accra Plains. Leaves of Samanea saman, Acacia auriculiformis and Ficus exasperata and cassava peels were dried, mixed with other ingredients and pelleted. A preference trial showed sheep accepted all the four supplements with a marked preference for cassava peelsbased (CP-B) and Samanea saman-based (SL-B) supplements compared with Acacia auriculiformis-based (AL-B) and Ficus exasperata-based $(F L-B)$ supplements $(P<0.05)$. The supplements were subsequently fed to Eight West African Dwarf sheep on a basal diet of Andropogon gayanus (Gamba grass) hay in Latin square design. Dry matter intakes (DMI) did not differ by the type of supplement $(P>0.05)$. However, crude protein intake (CPI) was higher $(P<0.05)$ in sheep fed AL-B and FL-B than those fed SL-B and CP-B. Dry matter and neutral detergent fibre (NDF) digestibility were lowest $(P<0.05)$ for sheep fed CP-B. Dietary treatments did not affect haematological parameters, except for neutrophil percentage which was higher $(P<0.05)$ in sheep fed CP-B than those fed SL-B. Animals fed CP-B had the lowest monocyte concentrations $(P<0.05)$. Furthermore, all the serum biochemical parameters were not affected by dietary treatment except total protein concentration which was highest $(P<0.05)$ in sheep fed on AL-B. It is concluded that the feed resources available to the small ruminant keepers can be used to prepare pelleted supplements that are acceptable to sheep and help sustain appreciable performance on low quality forages during the dry season without any deleterious effects on intake, digestibility, physiology and health.
\end{abstract}

Keywords: Acceptability, Browse plants, Dry season, Accra Plains, Blood parameters, Feed intake

Abbreviations: AL-B: Acacia auriculiformis-based supplement; ADF: Acid detergent fibre; ADFD: Acid detergent fibre digestibility; ADFI: Acid detergent fibre intake; ANOVA: Analysis of variance; AOAC: Association of Official Analytical chemists; CP: crude protein; CPD: crude protein digestibility: CPI: crude protein intake; CP-B: cassava peel-based supplement; DM: dry matter; DMD: dry matter digestibility; DMI: dry matter intake; FCE: feed conversion efficiency; FL-B: Ficus exasperata-based supplement; LIPREC: Livestock and Poultry Research Centre; MCV: mean corpuscular volume; $\mathrm{MCH}$ : mean corpuscular hydrogen; MCHC: mean corpuscular hydrogen concentration; NDF: Neutral detergent fibre; NDFD: neutral detergent fibre digestibility; NDFI: neutral detergent fibre intake OM: organic matter: OMD: organic matter digestibility; OMI: organic matter intake; PCV: packed cell volume; RBC: red blood cell; SEM: standard error of mean; SL-B: Samanea saman-based supplement; T. Cholesterol: total cholesterol; WAD: West African Dwarf; WBC: white blood cell

\section{INTRODUCTION}

In the savannah areas of West Africa, where most livestock in the sub region are kept, the dry seasons are much longer than in the humid areas and are characterised by declines in forage availability and quality. For both cultivated pastures (Olanite et al., 2004) and natural pastures (Adjorlolo, 2014) forage biomass have been shown to decline drastically in the dry season. Other studies have indicated significant decreases in forage quality during the dry season. Even for forage legumes, decreases in crude protein content to as low as 5-7\% (Peters et al., 1997) and increases in neutral detergent fibre (Fujihara et al., 2004) during the dry season have been reported. Supplementation, either to increase the dry matter intake or to increase crude protein intake is often necessary for maintenance and possibly production. The use of fodder tree and shrub leaves as supplement is widely practiced by farmers in Ghana. However, during the late dry season, many trees shed their leaves and availability of tree leaves decline. Many small ruminant keepers resort to buying agroindustrial by-products such as wheat bran, rice bran and cassava peels from processing facilities for supplementary feeding.

An earlier study (Nsoh, 2019) identified feed resources commonly used by small ruminant keepers in the Accra Plains. This study sought to use four of the most important feed resources identified to develop pelleted multi-nutrient feed supplements with long shelf life, which can be stored and fed anytime during the year. It therefore assessed the effects of supplementary feed packages based on three browses and cassava peels on intake, metabolism and physiology of the West African Dwarf sheep. 


\section{MATERIALS AND METHODS}

\section{Study area}

The study was conducted at the Livestock and Poultry Research Centre (LIPREC) of the University of Ghana (05068' $\mathrm{N}, 00^{\circ} 10^{\prime} \mathrm{W}$ ) in the Coastal Savannah belt of Ghana, West Africa. Annual rainfall averages $881 \mathrm{~mm}$ per annum but with a high degree of variability. The rainy season was from April to June, the minor season was from September to October, and the dry season from November to March (Adjorlolo, 2014).

\section{Experimental animals and their management}

All animals used in the study were growing West African Dwarf sheep. The animals were housed in individual pens with concrete floors. The housing unit had roofs made of corrugated iron sheets. The pens were $3 \mathrm{~m} \times 1.5 \mathrm{~m}$ in dimension. Each pen had one wooden feeding trough for the basal diet and two plastic troughs, one for the supplement and the other for water. All the animals were treated against external parasites with pour-on acaricide and dewormed with Albendazole (10\%), a broad-spectrum anthelminthic. All the procedures in this study were approved by the Noguchi Memorial Institute for Medical Research Institutional Animal Care and Use Committee (NIACUC), University of Ghana (NIACUC Protocol No: 2017-03-2R).

\section{Preparation of experimental diets}

Three browse plants, Ficus exasperata, Samanea saman and Acacia auriculiformis, and cassava peels were identified in an earlier study (Nsoh, 2019) as the most important feed resources used in small ruminant feeding in the Accra Plains. These were selected for evaluation. Leaves of the browses were harvested from trees around LIPREC. The leaves as well as cassava peels, which was bought from cassava processors were shade dried for four to six days and ground in a hammer mill (1 $\mathrm{mm}$ screen) into meals. The meals were each mixed with conventional feed ingredients and micro-nutrients and pelleted (Table 1).

\section{Table 1 - Ingredient composition of supplements used in the acceptability study}

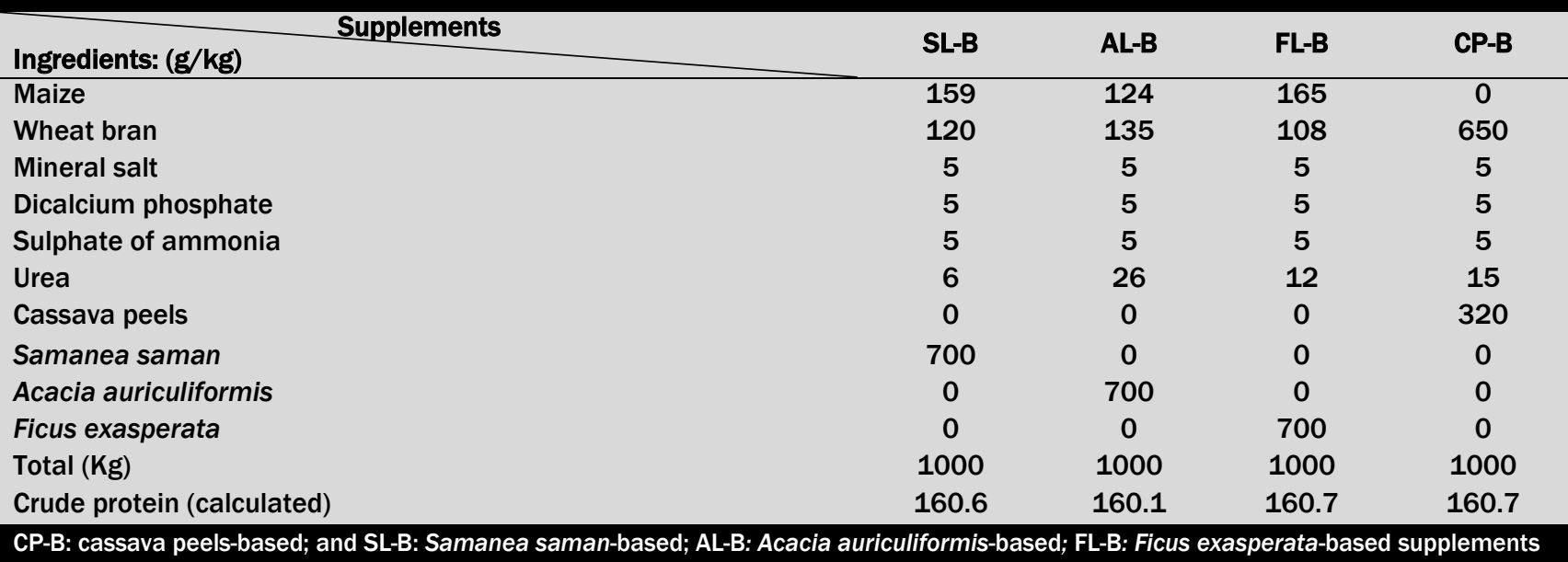

The pelleted supplements were formulated to be isonitrogenous using literature values of nitrogen concentrations in the browses and cassava peels. The dietary treatments were as follows:

Treatment $1(\mathrm{SL}-\mathrm{B})=$ Gamba grass hay + Samanea saman leaf meal-based supplement

Treatment $2(A L-B)=$ Gamba grass hay + Acacia auriculiformis leaf meal-based supplement

Treatment $3(\mathrm{FL}-\mathrm{B})=$ Gamba grass hay + Ficus exasperata leaf meal-based supplement

Treatment $4($ CP-B $)=$ Gamba grass hay + Cassava peel meal-based supplement

\section{Preference study}

Four female sheep with an average live weight of $13.7 \pm 1.5 \mathrm{~kg}$ were used for this trial. Each animal was penned individually and given free access to fresh water. Each sheep was offered the four supplements in a cafeteria style at 08:00 hours each day and were allowed one hour to select. After the one hour, the refusal was deducted from the feed offered to determine the amount of each supplement consumed. The Andropogon gayanus hay which acted as the basal diet, was then offered ad libitum. An adjustment period of 14 days was followed by a data collection period of seven days.

\section{Voluntary feed intake and digestibility study}

Eight female sheep with an average initial body weight of $14.9 \pm 1.5 \mathrm{~kg}$ were randomly allotted to four experimental diets in a replicated Latin square design. Animals on each treatment were offered Andropogon gayanus hay as the basal feed and supplemented with either SL-B, AL-B, FL-B or CP-B. A daily supplement allowance of approximately $25 \%$ of voluntary intake was offered as single meals at 08:00 hours followed by the grass hay offered ad libitum. An adjustment 
period of 14 days was followed by 74 days of data collection. Feed intake was determined daily as the difference between weight of feed offered and refusals. Rectal faecal samples were taken from each animal and bulked for each sheep for six days during the feed intake trial. The faecal samples were stored in a refrigerator. The faecal samples were then oven dried at $55^{\circ} \mathrm{C}$ to a constant weight for dry matter (DM) determination. The dried faeces were ground using a laboratory mill through $1 \mathrm{~mm}$ sieve and bagged for subsequent analysis.

Apparent digestibility (AD) of dry matter and other fractions of the feed were calculated as:

$\mathrm{AD}(\%)=100-\left(100 *\left(\frac{\text { Lignin in } \mathrm{feed}}{\text { Faecal lignin }}\right) \times\left(\frac{\text { Faecal lignin }}{\text { Total dry matter intake }}\right)\right)$ (de Oliveira et al., 2012)

Lignin was used as internal marker.

\section{Chemical analysis of feed and faeces}

Dry matter, organic matter, crude protein, and ash for the feed and faeces were determined using the method of AOAC (2004). Neutral detergent fibre (NDF), acid detergent fibre (ADF), lignin, cellulose, hemicellulose and silica were determined according to Van Soest et al. (1991).

\section{Blood sampling}

Blood samples were collected every two weeks (week 1, 3, 5, 7 and 9) from the jugular vein of each sheep using a vacutainer needle. Sampling was done in the morning, between 07:30 and 08:00 hours. A total of 10ml of blood sample was collected and $4 \mathrm{ml}$ transferred into a glass vacutainer tube containing the anticoagulant tripotassiumethelyne diamine tetra acetic acid (K3.EDTA). The tubes were placed on ice and transported immediately to the Laboratory for haematological analysis. The remaining $6 \mathrm{ml}$ was transferred into glass vacutainer tubes containing clot (Gel) activator. This was placed on ice pack and also transported to the Laboratory where it was centrifuged at 3000 rpm for 10 minutes at $4{ }^{\circ} \mathrm{C}$. The sera obtained were gently harvested into Eppendorf tubes and stored at $-20^{\circ} \mathrm{C}$ until the analyzed for biochemical parameters.

\section{Haematological analysis}

The haemoglobin concentration was determined by the cyanmethaemoglobin method (Gillet et al., 2009), while PCV was estimated by the microhaematocrit method (Samour, 2006). The RBC and WBC counts were determined using the haemocytometer.

Total RBC count was determined using the formula given by Samour $(2006): \mathrm{RBC}\left(10^{12} / \mathrm{L}\right)=\frac{\mathrm{N}}{100}$, Where: $\mathrm{L}=\mathrm{Litre} ; \mathrm{N}=$ Number of cells counted in 160 small squares.

The total WBC counts was estimated using the formula given by Campbell (1994): WBC $\left(10^{9} / \mathrm{L}\right)=\frac{\mathrm{N} \times 10 \times 200}{9}$, Where: $\mathrm{L}=$ litre; $\mathrm{N}=$ number of cells counted in nine small squares

The RBC indices were computed using the formulas provided by Reece and Swenson (2004) below:

$\operatorname{MCV}(\mathrm{fL})=\left(\frac{P V C}{R B C}\right) \times 10 ; \mathrm{MCH}(\mathrm{pg})=\left(\frac{H b}{R B C}\right) \times 10 ; \operatorname{MCHC}(\%)=\left(\frac{H b}{P C V}\right) \times 100$

In determining the differential WBC counts, thin smears of blood were made from blood samples obtained from venipuncture, on well ethanol-cleaned, grease-free microscope slides. They were air-dried, fixed in absolute methanol and stained with Giemsa stain. Stained slides were studied under oil immersion objective at $1000 \mathrm{X}$ magnification. Percentages of neutrophils, lymphocytes, monocytes, eosinophils and basophils were all determined based on observation of 200 WBC per film.

\section{Blood biochemical analysis}

The concentrations of glucose, total proteins, albumin, total cholesterol and urea were determined in the serum at weeks 1,3,5,7, and 9 using the Mindray BA -88A Semi-Auto Chemistry Analyzer. Globulin concentration was computed as the difference between total protein and albumin concentrations.

\section{Statistical analyses}

Data from the acceptability, feed intake and digestibility studies were subjected to Analysis of variance procedure (ANOVA) of GenStat Release 12th Edition (VSN International, 2009), whilst that of the blood parameters was analyzed using repeated measures analysis of variance procedure of GenStat (VSN International, 2009). The Least significant difference procedure of GenStat was used to separate the means at $5 \%$ level of significance.

\section{RESULTS}

\section{Chemical composition of feed ingredients and supplements}

The chemical composition of the basal diet (Gamba grass hay), the three browses (Samanea saman, Acacia auriculiformis and Ficus exasperata) and cassava peels are presented in Table 2. The basal diet, the leaf meals of the three browses and cassava peels had comparable dry matter contents (range 89.9 to 94.6\%) and organic matter (range $\mathbf{8 0 . 8}$ to $\mathbf{8 7 . 2 \% )}$ contents. The chemical composition of the supplements are shown in Table 3 . The dry matter, organic 
matter, NDF and lignin contents were similar. FL-B had the highest crude protein content (21.5\%) while CP-B had the least (16.3\%) crude protein but highest ADF.

\section{Preference of sheep for the pelleted supplements}

The sheep accepted all the supplements but preferred $(P<0.05)$ SL-B and CP-B to the rest. The supplement least preferred $(P<0.05)$ was FL-B. The preference of sheep for the three browses and cassava peel meal supplements is shown in Table 4.

\section{Influence of supplements on voluntary intakes in West African Dwarf sheep}

The influence of the supplements on voluntary intake in sheep is shown in Table 5. The total dry matter intake was similar ( $P>0.05$ ) across the treatments. Crude protein intake ranged from 59.63 to $67.01 \%$. Sheep fed AL-B and FL-B had similar crude protein intakes but significantly higher $(P<0.05)$ crude protein intake than those fed SL-B and CP-B. Organic matter intake was least $(P<0.05)$ in FL-B Sheep. However, intake of NDF was significantly higher $(P<0.05)$ in sheep fed FL$B$ than those fed the other treatments. The ADF intake on the other hand was in the range of 25.44 to $54.65 \mathrm{~g} / \mathrm{day}$ and was found to be significantly higher $(P<0.05)$ in sheep fed SL-B and CP-B than those fed AL-B and FL-B. Sheep CP-B had lower $(P<0.05)$ lignin intake than those fed SL-B, AL-B and FL-B.

\section{Digestibility of nutrients by West African Dwarf sheep}

Dry matter digestibility was lowest $(P<0.05)$ in sheep fed CP-B (Table 6). SL-B had the highest dry matter digestibility value of $62.35 \%$ and this was significantly $(P<0.05)$ higher than the digestibility of $60.33 \%$ for AL-B. The crude protein digestibility followed a similar pattern as dry matter digestibility. The organic matter digestibility in this study ranged from 46.31 to $52.25 \%$. Sheep fed SL-B had the highest $(P<0.01)$ organic matter digestibility. Also, sheep fed FL-B had higher $(P<0.05)$ organic matter digestibility than those fed AL-B and CP-B. The NDF digestibility in this study ranged from 34.9 for CP-B to $41.57 \%$ for FL-B. NDF digestibility was similar $(P>0.05)$ for sheep fed SL-B and FL-B, but both were higher $(P<0.05)$. The ADF digestibility in this study ranged from 22.30 to $33.47 \%$. The ADF digestibility was similar $(P>0.05)$ in sheep fed SL-B and CP-B, but both were higher $(P<0.05)$ than for AL-B and FL-B.

\section{Table 2 - Chemical composition of leaf meals of browses, cassava peel meal and Andropogon gayanus hay}

\begin{tabular}{lccccc} 
Fraction (\%) & $\begin{array}{c}\text { Andropogon } \\
\text { hay }\end{array}$ & Samanea & Acacia & Ficus & $\begin{array}{c}\text { Cassava } \\
\text { Peels }\end{array}$ \\
\hline Dry matter & 89.9 & 92.7 & 93.4 & 91.9 & 94.6 \\
Crude protein & 6.7 & 21.9 & 16.4 & 15.9 & 2.1 \\
Organic matter & 80.8 & 83.8 & 87.2 & 87.2 & 80.9 \\
Neutral detergent fibre & 73.8 & 59.8 & 60.7 & 42.9 & 36.3 \\
Acid detergent fibre & 44.9 & 39.7 & 49.5 & 36.4 & 27.4 \\
Lignin & 6.1 & 6.8 & 6.2 & 3.7 & 9.7 \\
Total ash & 12.6 & 8.9 & 6.2 & 3.7 & 7.3 \\
\hline
\end{tabular}

\section{Table 3 - Chemical composition of the experimental supplements}

\begin{tabular}{lcccc}
\multirow{2}{*}{ Fraction (\%) } & \multicolumn{4}{c}{ Supplement (\%) } \\
\cline { 2 - 5 } & SL-B & AL-B & FL-B & CP-B \\
\hline Dry matter & 92.5 & 91.7 & 90.2 & 91.2 \\
Crude protein & 18.3 & 20.5 & 21.5 & 16.3 \\
Organic matter & 85.9 & 84.7 & 83.7 & 84.8 \\
Neutral detergent fibre & 41.6 & 44.5 & 43.4 & 41.3 \\
Acid detergent fibre & 30.2 & 29.6 & 14.6 & 30.6 \\
Lignin & 3.8 & 4.7 & 4.5 & 3.4
\end{tabular}

CP-B: cassava peels-based; and SL-B: Samanea saman-based; AL-B: Acacia auriculiformis-based; FL-B: Ficus exasperata-based supplements

\section{Table 4 - Preference of West African Dwarf sheep for the supplements}

\begin{tabular}{lc} 
Supplements & Means of intake (g) \\
\hline CP-B & $223.3^{\mathrm{a}}$ \\
SL-B & $195.8^{\mathrm{a}}$ \\
AL-B & $111.3^{\mathrm{b}}$ \\
FL-B & $57.6^{\mathrm{c}}$ \\
SEM & 24.16 \\
P-Value & $<0.001$ \\
\hline a,b,c, Means within a column with different superscripts differ significantly at P<0.05.
\end{tabular}




\section{Table 5 - Influence of supplements on voluntary intakes in West African Dwarf sheep}

\begin{tabular}{|c|c|c|c|c|c|c|}
\hline Parameter (g/day) $\quad$ Supplements & SL-B & AL-B & FL-B & CP-B & SEM & P-value \\
\hline Dry matter intake & 649.5 & 636.8 & 629.6 & 653.3 & 11.52 & 0.143 \\
\hline Crude protein intake & $63.69^{b}$ & $67.01^{\mathrm{a}}$ & $66.32^{a}$ & $59.63^{c}$ & 1.277 & $<0.001$ \\
\hline Organic matter intake & $533.6^{a}$ & $520.9^{a}$ & $497.3^{b}$ & $534.4^{a}$ & 9.40 & $<0.001$ \\
\hline Neutral detergent fibre intake & $74.36^{b}$ & $76.75^{b}$ & $85.98^{a}$ & $72.98^{b}$ & 2.042 & $<0.001$ \\
\hline Acid detergent fibre intake & $54.65^{a}$ & $50.81^{b}$ & $25.44 c$ & $53.79 a$ & 1.158 & $<0.001$ \\
\hline Lignin intake & $35.49 a$ & $36.56^{a}$ & $36.17^{a}$ & $34.14^{b}$ & 0.629 & $<0.001$ \\
\hline
\end{tabular}

a,b,c, Means within a row with different superscripts differ significantly at P<0.05.; CP-B: cassava peels-based; and SL-B: Samanea samanbased; AL-B: Acacia auriculiformis-based; FL-B: Ficus exasperata-based supplements.

Table 6 - Digestibility of components of feed as influenced by supplementation (\%)

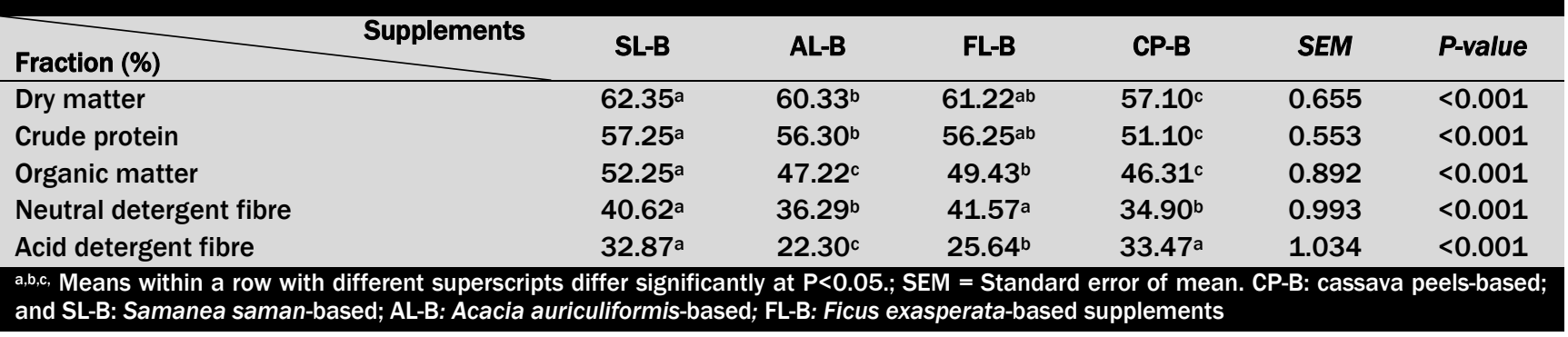

\section{Haematological and serum biochemical parameters in West African Dwarf sheep}

Details of the effects of the supplements on haematological and serum biochemical parameters of sheep are shown in Table 7. There was no significant treatment effect $(P>0.05)$ on most of the haematological parameters measured except neutrophils and monocyte levels. Sheep that were fed the CP-B had significantly $(P<0.05)$ higher neutrophil value than those fed on SL-B. Values for sheep on AL-B and FL-B, however, were not significantly different $(P>0.05)$ from those on SL-B and CP-B. Sheep on SL-B and AL-B had significantly $(P=0.05)$ higher monocyte concentrations than those on CP-B. Dietary treatment did not significantly $(P>0.05)$ affect all the serum biochemical parameters determined except total protein concentration which was significantly $(P<0.05)$ higher in sheep fed on $A L-B$ than those fed on SL-B, FL-B and CP-B. Generally, the concentrations of most of the haematological and serum biochemical parameters remained relatively stable and showed similar trends across dietary treatments during the period of study (Figures 1 and 2).

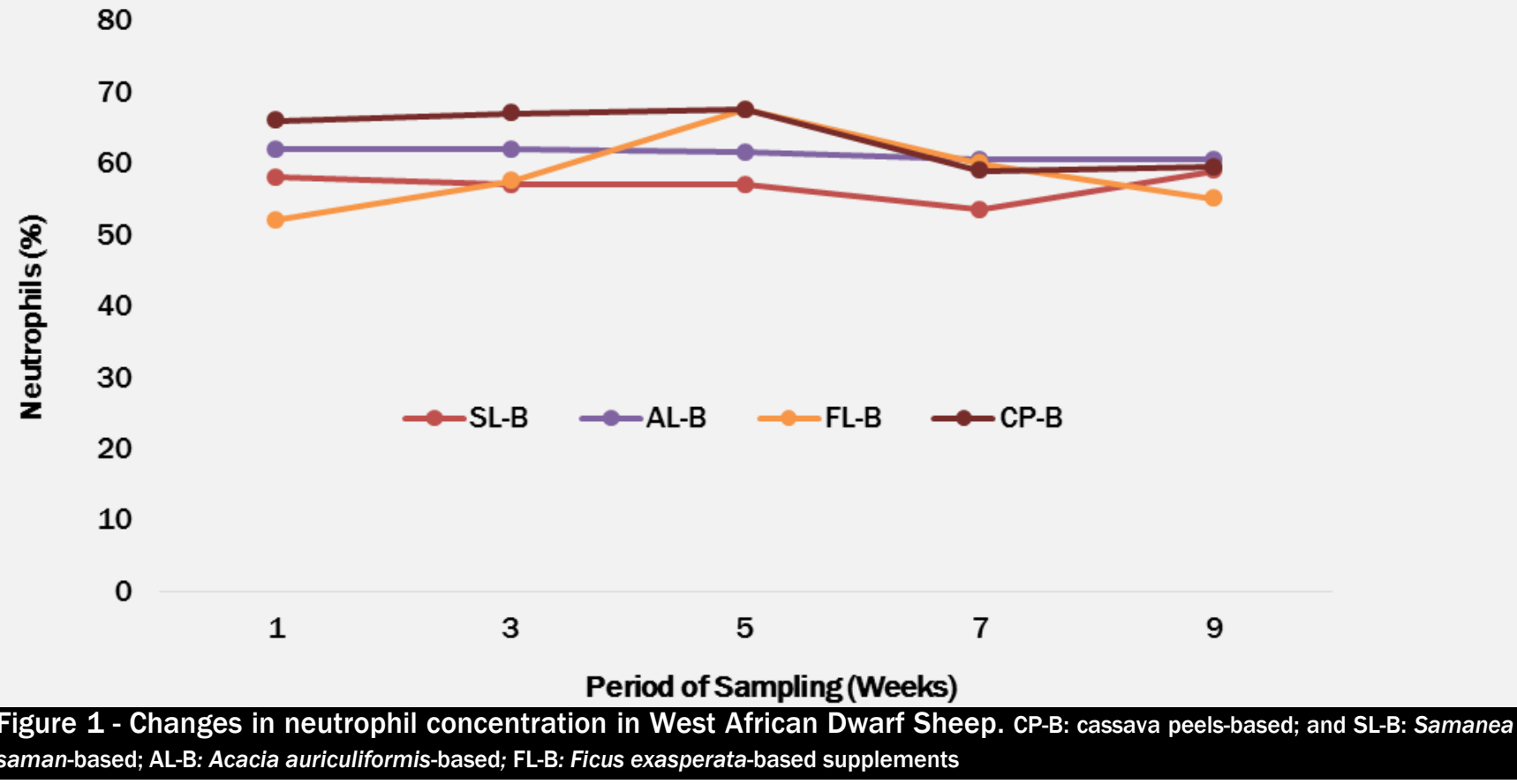




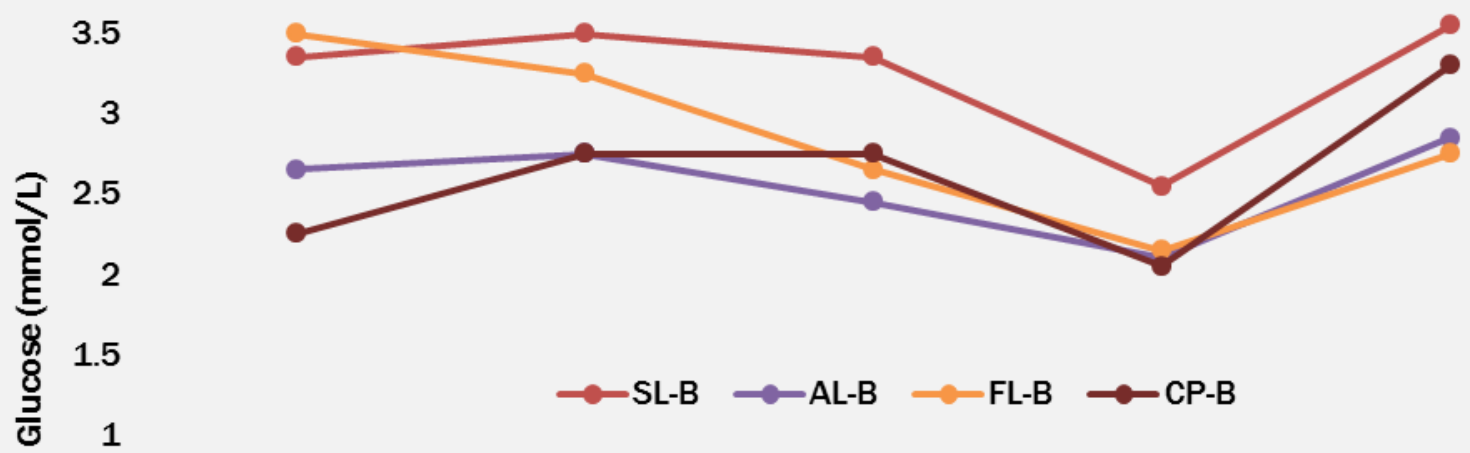

0.5

0
1
3
5
7
Period of sampling(Weeks)

9

Figure 2 - changes in Glucose concentration in West African Dwarf Sheep. CP-B: cassava peels-based; and SL-B: Samanea saman-based; AL-B: Acacia auriculiformis-based; FL-B: Ficus exasperata-based supplements

Table 7 - Haematological and serum biochemical parameters of West African Dwarf sheep fed basal diet of Andropogon gayanus hay and supplements

\begin{tabular}{|c|c|c|c|c|c|c|}
\hline \multirow{2}{*}{ Parameters } & \multicolumn{4}{|c|}{ Treatments } & \multirow{2}{*}{ SEM } & \multirow{2}{*}{ P-value } \\
\hline & SL-B & AL-B & FL-B & CP-B & & \\
\hline \multicolumn{7}{|l|}{ Haematological Indices } \\
\hline Haemoglobin (g/dL) & 13.27 & 15.27 & 15.33 & 15.46 & 1.01 & 0.162 \\
\hline PCV (\%) & 29.20 & 33.60 & 32.80 & 35.60 & 2.05 & 0.291 \\
\hline $\mathrm{RBC}\left(\mathrm{x} 10^{12} \mathrm{~g} / \mathrm{L}\right)$ & 10.63 & 11.94 & 11.80 & 11.24 & 0.66 & 0.160 \\
\hline $\operatorname{MCV}(f L)$ & 27.80 & 27.87 & 28.73 & 29.45 & 0.14 & 0.577 \\
\hline $\mathrm{MCH}(\mathrm{pg})$ & 12.40 & 12.87 & 13.26 & 13.92 & 0.07 & 0.157 \\
\hline $\mathrm{MCHC}(\mathrm{g} / \mathrm{dL})$ & 45.44 & 45.24 & 46.74 & 43.43 & 0.15 & 0.053 \\
\hline WBC(x109/L) & 4.37 & 4.96 & 4.34 & 4.87 & 0.39 & 0.641 \\
\hline Neutrophils (\%) & $56.90^{b}$ & $61.30^{\mathrm{ab}}$ & $58.40^{\mathrm{ab}}$ & $63.80^{a}$ & 4.37 & 0.037 \\
\hline Lymphocyte (\%) & 39.20 & 34.60 & 39.30 & 34.70 & 4.10 & 0.487 \\
\hline Eosinophils (\%) & 1.60 & 1.50 & 0.80 & 0.80 & 0.80 & 0.625 \\
\hline Monocytes (\%) & $2.20^{a}$ & $2.30^{a}$ & $0.90^{\mathrm{ab}}$ & $0.50^{\mathrm{b}}$ & 0.73 & 0.50 \\
\hline Basophils (\%) & 0.09 & 0.11 & 0.22 & 0.18 & 0.10 & 0.596 \\
\hline \multicolumn{7}{|l|}{ Serum Biochemical Indices } \\
\hline Glucose (mmol/L) & 1.96 & 1.54 & 1.72 & 1.57 & 0.20 & 0.108 \\
\hline Total protein $(\mathrm{g} / \mathrm{L})$ & $60.46^{b}$ & $64.38^{a}$ & $61.48^{b}$ & $61.57^{b}$ & 0.65 & 0.030 \\
\hline Albumen $(\mathrm{g} / \mathrm{L})$ & 36.96 & 38.43 & 37.07 & 37.37 & 0.78 & 0.374 \\
\hline Globulin $(\mathrm{g} / \mathrm{L})$ & 23.50 & 25.95 & 24.41 & 24.14 & 1.23 & 0.388 \\
\hline T. cholesterol (mmol/L) & 1.40 & 1.50 & 1.48 & 1.79 & 2.87 & 0.497 \\
\hline Urea $(\mathrm{mmol} / \mathrm{L})$ & 9.51 & 9.67 & 8.71 & 9.21 & 0.36 & 0.492 \\
\hline
\end{tabular}

\section{DISCUSSION}

All the supplements were acceptable but SL-B and CP-B had the highest preference by sheep. A number of factors may influence acceptability of feed by small ruminants. Provenza and Cincotta (1994) reported that plant physical structure and chemical composition are the most vital factors that influence preference for feed. Oldham and Alderman (1982) reported that ad libitum intake by animals is increased by an increase in crude protein content of diets. However, in this study, no association between crude protein concentration and preference could be established.

The similarity in dry matter intakes may suggest that the supplements stimulated intake of the basal diets to similar extents despite the differences in the crude protein concentrations. The higher crude protein intake in sheep fed AL-B and FL-B compared to the SL-B and CP-B could be attributed to higher crude protein concentration of the supplements of AL-B and FL-B. High crude protein intake makes available nitrogen needed to improve the rumen eco-system and increase the animal's ability to digest fibrous portions of feed. Odedire and Oloidi (2014) reported a decrease in crude protein intake 
due to reduced palatability of the diet when West African Dwarf goats were fed supplements containing increasing levels of wild sunflower. In the current study however, dry matter intakes were similar. The lower organic matter intake in sheep fed FL-B could be attributed to the high levels of anti-nutritional factors, such as alkaloids, saponins, cyanogenic glycosides and tannins contained in that supplement that could potentially have adverse effects on nutrient utilization as reported by Ljeh and Ukwemi (2007). The higher NDF intake of sheep fed FL-B could be attributed to the higher crude protein level in FL-B (21.5\%) which could have improved rumen environment aiding rumen microbial fermentation thereby increasing dry matter intake and consequently, NDF intake. The high intake of ADF in sheep fed SL-B and CP-B may be due to moderate quantities of antinutritional factors in SL-B (Obasi et al., 2010) and tolerable levels of cyanogenic glycosides in CP-B which might not have adversely influenced the rumen environment but rather aided in ADF digestion thereby increasing its intake. The lower lignin intake in sheep fed CP-B compared to those fed SL-B, AL-B and FL-B could be attributed to an imbalance or inadequacy of nutrients especially crude protein intake in sheep fed CP-B which might have resulted in reduced rumen ammonia production and microbial growth and activity. This could indirectly slow down the rates of digestion and passage and subsequently reduce intake as reported by Preston and Leng (1987).

The lower dry matter digestibility in sheep fed CP-B compared to the other treatments could be attributed to lower crude protein intake of this supplement. Also, anti-nutritional factors such as cyanogenic glycosides in the cassava peels might have slowed down microbial action and thereby decreased dry matter digestibility. Anti-nutritional factors are known to interfere with normal digestion, metabolism and absorption of nutrients (Gilani et al., 2005). The leaves of forages are high in readily degradable nitrogen as reported by NRC (2000) and some by-pass protein. Inclusion of such browses in ruminant diets cause faster fermentation rate and substrate degradation hence increasing dry matter intake. The higher crude protein intake of sheep fed SL-B, AL-B and FL-B over CP-B could have enhanced the digestibility of crude protein in these supplements than the CP-B. The presence of cyanogenic glycosides in the cassava peel meal supplement could have inhibited the effective digestion of protein by the rumen microbes. The leaves of forages are high in readily degradable nitrogen as reported by NRC (2000) and some by-pass protein. Inclusion of such browses in ruminant diets will cause faster fermentation rate and substrate degradation hence increasing dry matter intake.

The high digestibility of organic matter of sheep fed SL-B and FL-B could be due to the provision of adequate nutrients to the rumen microbes with consequent improvement in organic matter intake whilst higher levels of flavonoids and triterpenoids in AL-B and cyanogenic glycosides in CP-B adversely affected rumen microbial activity resulting in lower organic matter digestibility. Also, the lower crude protein digestibility in sheep fed CP-B may account for their lowest organic matter digestibility.

The high NDF digestibility in sheep fed SL-B and FL-B is likely due to moderate concentrations of secondary metabolites in the Samanea and Ficus leaf meals that might have had positive influence on rumen microbes as several researchers have reported secondary metabolites having positive impacts on rumen fermentation due to their low or moderate concentrations (Jiménez-Peralta et al., 2011; Salem et al., 2014). The low crude protein level in CP-B could have inhibited rumen activity thus decreasing digestibility of NDF of sheep fed that diet. However, ADF digestibility in sheep fed CP-B was higher probably as a result of low lignin contents in CP-B compared with the others.

Haematological and blood biochemical indices provide useful information on the physiological status of animals and hence serve as a tool in determining normal healthy state of animals (Onasanya et al., 2015). The similar concentrations of the haematological parameters in most of the test diets suggest that the inclusion of the supplements did not have adverse or detrimental effects on the health of the sheep. This suggests the quality of the supplementary diets were good to help sustain growth of sheep during periods when animals have to rely of poor quality fodder. The haemoglobin and PCV levels of 13.27 to $15.46 \mathrm{~g} / \mathrm{dL}$ and 29.20 to $35.60 \%$ respectively obtained in the present study were within the normal physiological range of 9 to $15 \mathrm{~g} / \mathrm{dL}$ and 27 to $45 \%$ respectively reported for sheep (The Merck Veterinary Manual, 2010). This suggests similar ability of the dietary treatments in augmenting the production of haemoglobin and RBCs for efficient transportation of gases during respiration. Konlan et al. (2012) and Dougba (2017) in earlier studies reported haemoglobin and PVC ranges of 12.41 to $13.60 \mathrm{~g} / \mathrm{dL}$ and 27.45 to $29.43 \%$ respectively for the same breed of sheep fed diets containing various agro-industrial by-products. Total RBC counts range of values (10.63 to $\left.11.94 \mathrm{x} 10^{12} \mathrm{~g} / \mathrm{L}\right)$ was within the normal physiological range of 9 to $15 \times 10^{12} \mathrm{~g} / \mathrm{L}$ reported for sheep (The Merck Veterinary Manual, 2010) indicating the efficient synthesis of RBCs across the dietary treatments. The MCV, MCH and MCHC values obtained in the present study were also comparable to the normal physiological range for sheep. The total WBC counts $\left(4.34 \times 10^{9}\right.$ to $4.96 \times 10^{9} \mathrm{~g} / \mathrm{L}$ obtained in the present study were within the normal range of $4 \times 10^{9}$ to $12 \times 109 / \mathrm{L}$ reported for sheep (The Merck Veterinary Manual, 2010). This suggests the test diets supplied enough nutrients for the production of WBCs to adequately defend the body against infections. Konlan et al. (2012) reported a range of $8.37 \times 10^{9}$ to $9.30 \times 10^{9}$ for the West African Dwarf sheep fed a basal diet of rice straw and groundnut haulms with graded levels of shea-nut cake supplement. Also, the WBC differential counts across dietary treatments were within the normal ranges reported for sheep (The Merck Veterinary Manual, 2010). This suggests similar ability of the sheep to fight infection when fed the supplements. The distribution of WBC observed in the present study were comparable with the range of values reported for the same breed of sheep by Baiden and Obese (2010) and Konlan et al. (2012).

The nonsignificant difference in the concentrations of most of the blood biochemical parameters across the dietary treatments suggest that the inclusion of leaf meal supplements based on Samanea, Acacia, Ficus, and Cassava peel meal-based supplements did not have adverse effects on the physiology of the West African Dwarf sheep. The similar concentration of serum glucose across dietary treatments suggest the inclusion of the browse species leaf meal and 
cassava peel-based supplements did not adversely deprived the sheep of energy for metabolic activities. The range of values (1.54 to $1.96 \mathrm{mmol} / \mathrm{L}$ ) obtained in the present study was however, lower than the 2.85 to $3.10 \mathrm{mmol} / \mathrm{L} \mathrm{reported}$ for West Africa Dwarf sheep fed basal diet of rice straw and supplemented with varying levels of neem leaf meal concentrate diets (Dougba, 2017). Serum concentrations of total protein, albumin and globulin serve as indicators of protein status (Ndlovu et al., 2007). Also, circulating concentrations of globulin usually give indication of an animal's immune state and its response to fighting diseases and infections (Kapele et al., 2008). The higher crude protein intake for sheep fed AL-B than those fed the other three supplements may account for its high total protein value. The values obtained for total protein concentrations, 60.46 to $64.38 \mathrm{~g} / \mathrm{L}$ were within the normal physiological range of 59 to $78 \mathrm{~g} / \mathrm{L}$ reported for sheep (The Merck Veterinary Manual, 2010). The total protein concentrations were comparable to the 56.00 to $61.34 \mathrm{~g} / \mathrm{L}$ reported for the same breed of sheep fed basal diet of rice straw and groundnut haulms with graded levels of shea nut cake concentrate supplement (Konlan et al., 2012), but lower than the 72.3 to $83.3 \mathrm{~g} / \mathrm{L}$ reported for the same breed of sheep (Dougba, 2017). The age, type of diet fed and physiological state of the sheep used may account for the differences. The concentrations of serum albumin (36.96 to $38.43 \mathrm{~g} / \mathrm{L}$ ) were similar to the reported normal physiological values of 27 to $37 \mathrm{~g} / \mathrm{L}$ reported for sheep (The Merck Veterinary Manual, 2010). However, globulin concentrations (23.50 to $25.95 \mathrm{~g} / \mathrm{L}$ ) in the present study were lower than the reported normal physiological values of 39 to $60 \mathrm{~g} / \mathrm{L}$ in sheep (The Merck Veterinary Manual, 2010). The low globulin concentrations in the sheep may indicate low ability of the sheep to resist infections or diseases. All the sheep used in the study were however healthy and did not show any signs of disease throughout the study. The normal and similar total protein and albumin concentrations in sheep fed the various supplements indicates that the inclusion of leaf meal and cassava peel - based supplements did not adversely influence the availability of protein to the sheep, their immune status and ability to fight diseases. The range of values for total cholesterol (1.40 to $1.50 \mathrm{mmol} / \mathrm{L}$ ) was within the reported normal physiological range of 1.1 to $2.3 \mathrm{mmol} / \mathrm{L}$ in sheep (the Merck Veterinary Manual, 2010). However, the concentrations of serum urea (range 8.71 to $9.67 \mathrm{mmol} / \mathrm{L}$ ) in the present study was close to the normal physiological upper range value of $9.3 \mathrm{mmol} / \mathrm{L}$ reported for sheep (The Merck Veterinary Manual, 2010), but lower than the values 13.26 to $16.32 \mathrm{mmol} / \mathrm{L}$ reported for West African Dwarf sheep fed basal diet of rice straw and supplemented with varying levels of neem leaf meal concentrate diets (Dougba, 2017). The difference may be attributed to the type of diet fed to sheep in these studies.

\section{CONCLUSION}

From the above studies, feed resources available to the small ruminant keepers can be used to prepare pelleted supplements that are acceptable to sheep and help improve performance on low quality forages. Feeding these supplements did not adversely affect the health and physiology of sheep as indicated by the blood parameters. These supplements, which have high bulk density and long shelf life, can help prevent the major losses in ruminant production during the dry season.

\section{DECLARATIONS}

\section{Corresponding Author}

E-mail: fobese@ug.edu.gh; ORCiD: 0000-0001-6747-4786

\section{Authors' Contribution}

LA conceived the study, participated in the design of the study, contributed to data analysis and the write up of the manuscript, MS participated in the data collection and contributed in data analysis and the write up of the manuscript, AM was in involved the design and data analysis of the study and contributed to the write up of the manuscript. FO participated in the design and coordination of the study, contributed to data analysis and the write up of the manuscript.

\section{Conflict of interests}

The authors have not declared any conflict of interests.

\section{Acknowledgements}

This project was made possible with financial support from the University of Ghana research fund and funds from the AG Leventist Foundation.

\section{REFERENCES}

Adjorlolo LK, Adogla-Bessa T, Amaning-Kwarteng K and Ahunu BK (2014). Seasonal effect on rumen function in sheep on range in the Accra Plains of Ghana. Tropical Animal Health and Production, 46 (7): 1223-1228. D0I: https://doi.org/10.1007/s11250-0140629-y I Google Scholar

Adu IF, Fajemisin BA, Adamu AM. (1992). The utilisation of sorghum stover fed to sheep as influenced by urea or graded levels of lablab supplementation. In1. Biennial Conference of the African Small Ruminant Research Network, Nairobi (Kenya), 10-14 Dec 1990 1992. ILCA. AGRIS I Google Scholar

AOAC, (2004). Official Methods of Analysis. 18 ${ }^{\text {th }}$ Ed, Association of Official Analytical Chemists, Washington, DC. Link

Baiden RY and Obese FY (2010). Performance of West African Dwarf sheep (the Djallonké) fed fattening diets containing agro-industrial by-products in Ghana. Ghanaian Journal of Animal Science Ghanaian 5:60-65. Google Scholar 
Baiden RY, Rhule SWA, Otsyina HR, Sottie ET and Ameleke G (2007). Performance of West African dwarf sheep and goats fed varying levels of cassava pulp as a replacement for cassava peels. Livestock Research for Rural Development, 19(3), Article \# 35. DOI: http://www.Irrd.org/Irrd19/3/baid19035.htm I Google Scholar

Campbell TW (1995). Avian Hematology and Cytology. 2nd Edn., lowa State University Press, Ames, lowa, USA. Google Scholar I CabDirect

de Oliveira K, Costa C, Bittar CMM, dos Santos VP, Oliveira VAB and de Sá JC (2012). Indigestible cellulose and lignin in determining feces production and apparent digestibility in horses. Acta Scientiarum, Animal Sciences, 34 (3): $267-272$. D0I: https://doi.org/10.4025/actascianimsci.v34i3.10577 I Google Scholar

Dougba DT (2017). Effects of neem leaf meal supplementary diets on blood profiles of West African Dwarf sheep, M. Agric. Dissertation. Department of Animal Science. University of Ghana, Legon. Google Scholar

Evitayani L, Warly A, Fariani T, Ichinohe SA and Fujihara, AT (2004). Comparative rumen degradability of some legume forages between wet and dry season in West Sumatra, Indonesia. Asian-Australasian Journal of Animal Sciences, 17 (8): 1107-1111. D0I: https://doi.org/10.5713/ajas.2004.1107 I Google Scholar

Gilani GS, Cockell KA and Sepehr, E (2005). Effects of Antinutritional Factors on Protein Digestibility and amino Acid Availability in Foods. Journal of AOAC International, 88 (3): 967-987. https://watermark.silverchair.com/jaoac0967.pdf?token I Google Scholar

Gillet P, Boei L and Jacobs J (2009). Practical Note: Tropical Haematology. Antwerpen: Prince Leopold Institute of Tropical Medicine. Google Scholar

Jiménez-Peralta FS, Salem AZM, Mejia-Hernández P, González-Ronquillo M, Albarrán-Portillo B, Rojo-Rubio R and Tinoco-Jaramillo JL (2011). Influence of individual and mixed extracts of two tree species on in vitro gas production kinetics of a high concentrate diet fed to growing lambs. Livestock Science, 136 (2-3): 192-200. DOI: https://doi.org/10.1016/j.livsci.2010.09.008 I Google Scholar

Konlan SP, Karikari PK and Ansah T (2012). Productive and blood indices of dwarf rams fed a mixture of rice straw and groundnut haulms alone or supplemented with concentrates containing different levels of shea nut cake. Pakistan Journal of Nutrition, 11(6): 566-571. http://udsspace.uds.edu.gh/ispui/bitstream/123456789/559/1 I Google Scholar

Merck Veterinary Manual (2010). A handbook of diagnosis, therapy, and disease prevention and control for the veterinarian. Eds: Kahn CM and Line S, Merck and Co. Inc., New Jersey, USA, 905-908. Google Scholar

NRC (2000). Nutrient Requirements of Beef Cattle. 7th Review. ed. National Academy Press, Washington, DC. Google Scholar

Nsoh MA (2019). Nutritional evaluation of three browse species commonly fed to small ruminants by farmers in the Accra Plains of Ghana. MPhil Thesis. Department of Animal Science, University of Ghana. http://ugspace.ug.edu.gh/handle/123456789/34752 I Google Scholar

Odedire JA and Oloidi FF (2014). Feeding wild sunflower (Tithonia diversifolia Hemsl., A. Gray) to West African Dwarf Goats as a dry season forage supplement. World Journal of Agricultural Research, 2 (6): 280-284. D0I: https://doi.org/10.12691/wjar-2-6-6 I Google Scholar

Olanite JA, Tarawali SA and Aken'ova ME (2004). Biomass yield, quality and acceptability of selected grass-legume mixtures in the moist savanna of West Africa. Tropical Grasslands, 38: 117-128. Google Scholar

Oldham JD and Alderman G (1982). Recent advances in understanding protein-energy interrelationships in intermediary metabolism of ruminants. Protein and energy supply for high production of milk and meat. Pergamon Press, Oxford. Google Scholar

Onasanya, G. O., Oke, F. O., Sanni, T. M. and Muhammad, A. I., 2015. Parameters influencing haematological, serum and bio-chemical references in livestock animals under different management systems. Open Journal of Veterinary Medicine, 5 (8): 181-189. D0I: https://doi.org/10.4236/ojvm.2015.58025 I Google Scholar

Peters M, Tarawali SA and Alkamper J (1997). Dry season performance of four tropical pasture legumes in subhumid West Africa as influenced by superphosphate application and weed control. Tropical Grasslands, 31: 201-213 I Google Scholar

Provenza FD, Lynch JJ, Burritt EA and Scott CB (1994). How goats learn to distinguish between novel foods that differ in postingestive consequences. Journal of Chemical Ecology, 20: 609-624. DOI: https://doi.org/10.1007/BF02059601 I Google Scholar

Reece WO and Swenson MJ (2004). The composition and functions of blood. In: Reece, W.O. (ed). Duke's Physiology of Domestic Animals. 12th ed. Comstock Publishing Associates, Cornell University Press. Ithaca and London. p 26-51. Google Scholar

Salem MZM, Ali HM and Basalah MO (2014). Essential oils from wood, bark, and needles of Pinus roxburghii Sarg from Alexandria, Egypt: Antibacterial and antioxidant activities. BioResources, 9(4): 7454-7466. https://bioresources.cnr.ncsu.edu/wpcontent/uploads/2016/06/BioRes_09_4_7454 I Google Scholar

Samour J (2006). Diagnostic value of hematology. In ‘Clinical Avian Medicine’. (Eds GJ Harrison and TL Lightfoot.) pp. 587-607. Google $\underline{\text { Scholar }}$

Van Soest PV, Robertson JB and Lewis BA (1991). Methods for dietary fibre, neutral detergent fibre, and nonstarch polysaccharides in relation to animal nutrition. Journal of Dairy Science, 74(10): 3583-3597. D0I: https://doi.org/10.3168/jds.S0022$\underline{0302(91) 78551-2}$ I Google Scholar 